\section{Determinants of service quality and its effect on customer satisfaction and loyalty: an empirical study of private banking sector}

\author{
Rafikul Islam \\ Business Administration, International Islamic University Malaysia, \\ Kuala Lumpur, Malaysia \\ Selim Ahmed \\ World School of Business, World University of Bangladesh, Dhaka, Bangladesh \\ Mahbubar Rahman \\ Department of Marketing, Faculty of Business Studies, University of Rajshahi, \\ Rajshahi, Bangladesh, and \\ Ahmed Al Asheq \\ World School of Business, World University of Bangladesh, Dhaka, Bangladesh
}

Determinants of service quality

\begin{abstract}
Purpose - The main purpose of this study is to investigate the impact of various service quality dimensions, namely reliability, responsiveness, visibility, employee commitment and access to service on customer satisfaction in the private banking sector of Bangladesh. The research also investigates the relationship between customer satisfaction and loyalty and effect of demographic variables on customer satisfaction. Design/methodology/approach - The researchers distributed 320 self-administered survey questionnaires among private banks' customers in Bangladesh and obtained 200 useable responses with a $62.5 \%$ valid response rate. The research data were analysed using confirmatory factor analysis (CFA) and structural equation modelling (SEM) approaches. Analysis of variance and logistic regression have also been used to obtain the supplementary findings.

Findings - Theresearch findings indicate that visibility, responsiveness and employee commitment have positive and significant effect on customer satisfaction, whereas reliability and access to service are found to have insignificant influence on customer satisfaction of private banking services. The findings of this study also revealed that customer satisfaction has positive and significant relationship with customer loyalty. But except respondents' occupation type, all other demographic variables have no statistically significant relation with customer satisfaction. Research limitations/implications - The research focused solely on the private banking sector of Bangladesh, and thus the results may not be applicable to other service sectors.

Originality/value - This study conducted on customers' perception of private banking services is based on extended service quality dimensions and its relationship with customer satisfaction towards loyalty. The present research findings are anticipated to offer the guidelines for improving the customer satisfaction and loyalty of private banking services in Bangladesh as well as other countries.
\end{abstract}

Keywords Private banking, Service quality, Customer satisfaction, Customer loyalty, Structural equation modelling

Paper type Research paper

\section{Introduction}

The economic and societal developments of countries all over the world largely depend on the contribution of their service sector (Yalley and Agyapong, 2017). At present, the service

The authors would like to thank the anonymous reviewers for their insightful and constructive comments which have been helpful to improve the content as well as quality of the article.

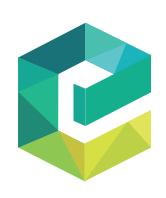

The TQM Journal Vol. 33 No. 6, 2021 pp. $1163-1182$ (C) Emerald Publishing Limited 1754-2731 
TQM

33,6

1164

sector is considered as the most important growth engine as it creates and enlarges the wealth of a nation. As a service sector, banks play a vital and active role in this context. The economic growth of a country is positively influenced by its effective banking system (Ayadi et al., 2015). However, the practitioners of this industry face a number of complex challenges when they operate their businesses in a dynamic, competitive situation. Therefore, it is important for the banks to better understand these challenges and meet the changing needs of the customers in order to compete more effectively with other service providers. Considering this, banks need to offer a diverse portfolio of competitive services and progressively redesign their services to meet the changing needs of their customers.

All types of customers - whether retail or corporate, are important to banks. Therefore, customer satisfaction is an important ingredient for this industry which is closely related with service quality (Spreng and MacKoy, 1996; Silvestri et al., 2017). Improved service quality leads to increased probability of customer satisfaction. On the other hand, better customer satisfaction results in a number of behavioural outcomes such as commitment, customer retention, building bonds, increasing customer tolerance for service failures and positive word of mouth (Berry et al., 1989; Gounaris et al., 2003; Oh and Kim, 2017). Özkan et al. (2019) conclude that the most crucial determinant for success in banking industry is service quality.

The service quality is treated as the most important precursor for surviving in the competitive environment. Sustainable competitive advantage can be achieved by providing best possible services. High service quality differentiates service providers from their competitors by increasing profitability, attracting new customers, reducing cost, enhancing stakeholders' satisfaction, improving customer retention and thus enhancing the corporate image (Gounaris et al., 2003). Furthermore, new customers are attracted through positive word of mouth (Caruana 2002). In essence, the level of customer satisfaction closely relates to service quality offered by the service providing firms. Thus, enhancement of customer satisfaction, in turn, leads to stronger customer loyalty (Heskett et al., 1997; Kashif et al., 2015; Kaur and Soch, 2018).

Changing needs of bank customers makes operations of banks more challenging. This requires incorporation of new forms of banking services, such as electronic banking. However, customers still measure a bank's service quality in terms of personal support they receive rather than technical support (Wang et al., 2003). Therefore, in addition to providing an assortment of services, the banks should place more emphasis on quality of service. That is, the assortment of services offered is not a powerful means of differentiation as competitors can easily imitate it (Zhou, 2004). Thus, service quality is considered as key success factor in sustaining competitive advantages (Palmer, 2001). Therefore, a significant amount of work has been done to comprehend the nature and dimensions of service quality, customer satisfaction and customer loyalty across many different service industries.

\section{Context of the study}

The banking sector of Bangladesh is now passing through a situation of diversified patterns of ownership. A number of foreign and local stakeholders actively participate in this sector. For attracting a greater number of customers, all the banks in the country compete with each other which actually results in a long-term benefit for them. However, private commercial banks of the country are put under the direct supervision of the central bank. But a separate institutional framework does not exist for them. They are treated in the same way as other state-owned commercial banks. This constraints them to monitor the satisfaction issues of their customers. Therefore, in order to compete in the market, private commercial banks probably need to develop their own marketing strategies and give more emphasis to fulfil their customers' needs. In particular, there is a need for private commercial banks of Bangladesh to supply and maintain better service quality and customer satisfaction which may result in garnering greater customer loyalty. Saleh et al. (2017) investigated the 
perceptions of customers of Islamic and conventional banks in Bangladesh and identified the difference in perceptions. Overall, in Bangladesh context, there are dearth of focussed studies to measure the effects of service quality on customer satisfaction and loyalty in the private banking sector. Thus, the purpose of this study is to investigate the effect of service quality on customer satisfaction and loyalty and fill up the research gap.

\section{Literature review}

\subsection{Service quality}

The term "Service Quality" has gained a noteworthy and scholarly research attention in the academic literature (Nambiar et al., 2018). Service quality can be defined as the difference between what a services customer expects and what actually he/she experiences. This concept can be comprehended as an elaborative customer assessment of a specific service and the degree to which it does fulfil customers' perceived expectation and satisfaction level of the service (Aljazzazi and Sultan, 2017). Parasuraman et al. (1988) explained service quality as the "function of difference between service expected and customer's perceptions of the actual service delivered". Expectations deal with customers' prediction about a service what they can experience during the transaction. Expectations may vary due to customers' knowledge about a product or service (Kant and Jaiswal, 2017). A number of uncontrollable factors may influence on customers' expectations such as customers' previous experience of other companies and their promotional activities; customers' psychological condition at the time of delivering services; norms, values and background of the customers; image of the products which are delivered (Ahrholdt et al., 2017). In addition, Zeithaml et al. (1990) argued that customers' pre-purchase belief and opinions of surrounding people play an influential role in building service expectations of customers. Perceived performance is the actual perception of customers about the fulfilment of needs, wants and desires (Cadotte et al., 1987). Perceived quality is the feelings of customers regarding the performance of products or services. If the performance of services exceeds the expectations, it is regarded as of satisfactory service quality. Providing quality service is a prerequisite for a service firm to compete in the market (Anouze and Alamro, 2019). Satisfactory perceived quality creates customer satisfaction which ultimately results in customer loyalty (Singla, 2012). Hossain and Dwivedi (2015) investigated the role of confirmation in the context of service quality. Hossain et al. (2015) explored the role of TQM in managing retail banking operations.

In academic literature, two schools of thoughts were found in examining the dimensions of service quality (Ananda and Devesh, 2019). One school of thought of service quality was proposed by Grönroos (1984) that measures service quality from two dimensional aspects: technical and functional, and the second school of thought measures service quality using five dimensions: tangibility, reliability, responsiveness, assurance and empathy (Parasuraman et al., 1988), which is widely known as "SERVQUAL" model and has been applied to examine service quality in financial sector (Narteh, 2018; Yilmaz et al., 2018). Nonetheless, several researches pointed out that the five dimensions of "SERVQUAL" model might not hold in every country, and therefore service quality is perceived to be a multifaceted model which is essentially subject to cultural difference (Teeroovengadum, 2020). Therefore, the present study considers reliability, responsiveness, visibility, employee commitment and access to service as service quality dimensions and relationships with customer satisfaction and loyalty. Figure 1 illustrates the proposed model of service quality, customer satisfaction and customer loyalty in the private banking sector.

\subsection{Customer satisfaction}

To develop and foster a service-oriented business, the application of customer satisfaction has become a pivotal and essential matter for business firms (Cheshin et al., 2018). Customer
Determinants of service quality 
TQM

33,6

1166

satisfaction is a post-purchase action behaviour which indicates the feeling of the customers after using a particular product or service. It indicates the general assessment of customers on the basis of consuming the goods or services (Özkan et al., 2019). Customer satisfaction is the gap between pre-purchase expectation and disconfirmation (Ong et al., 2017). Kotler and Keller (2013) illustrated the term "customer satisfaction" as "a person's feeling of pleasure or disappointment which resulted from comparing a product's perceived performance or outcome against his or her expectations" (p. 110). More precisely, customer satisfaction relates with performance of the service provided (Asnawi et al., 2019). It can be referred to the customer's relative feelings that would arise from the perceived variance between customer's presumption and actual experience (Boonlertvanich, 2019). If the perception of customers about the performance of products or services exceeds expected levels, it results in positive disconfirmation for which continuous strong relationship can be built. On the other hand, perception of under-performance begets negative disconfirmation which may create discontinuity of the relationship and negative recommendations to others (Jamal and Naser, 2002). Mihelis et al. (2001) noticed that satisfaction of bank customers depends mostly on easy access to the facilities and behaviour of bank personnel rather than varieties of products and services offered, service dimensions and reputation of the bank. Amin and Isa (2008), when conducting a study on Malaysian banking industry, observed that smooth transaction system, friendly behaviour of staff, efficiency of services and confidentiality matters are the most influential factors for customer satisfaction.

\subsection{Customer loyalty}

The concept of customer loyalty has been critical for any business organization (Bhat et al., 2018), although it is imperatively a matter of challenge for a service firm to create and conserve loyal customers (Mainardes et al., 2020). Loyalty is a construct which includes multidimensional attributes (Zeithaml et al., 1996). Customer loyalty reflects the behavioural action, which is evolved within the customers, followed by repeat buying habits (Fida et al., 2020). Since the cost of attracting new customers is relatively higher than conserving the existing customers, hence retaining loyal customers is crucial for a service business firm. Research suggests that loyal customers exhibit a positive perception towards the business firm, purchase frequently and repeatedly from it and suggest other customers to buy from it (Levy and Hino, 2016). However, it is also noted that a loyal customer may not necessarily be a satisfied customer. For instance, customers who continue to repurchase from a particular firm due to absence of convenient alternatives are not loyal customers (Makanyeza and Chikazhe, 2017). This type of customers may turn to other service providers when they know that convenient alternatives become available. It may happen if customers are not satisfied on the existing services provided by the current service providers. In contrast, if customers

Figure 1.

Research framework and hypotheses

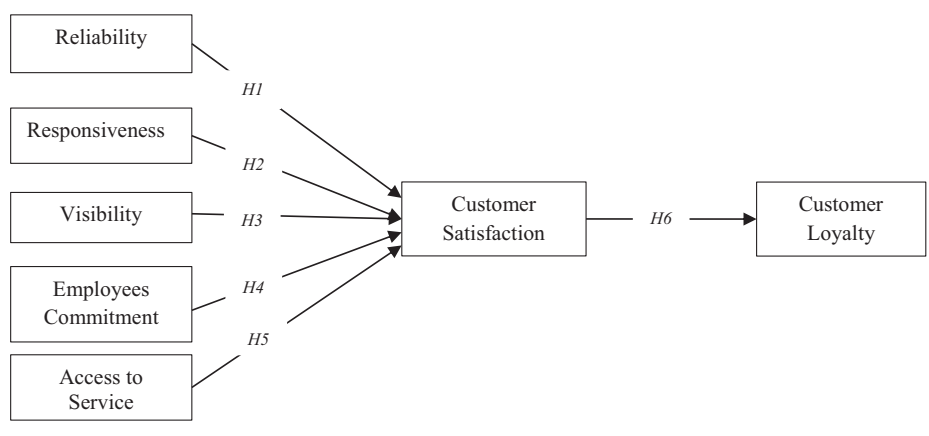


possess a positive attitudinal outlook towards their existing service providers, they may continue repurchasing from them. For measuring the customer loyalty of the bank, it is important to count the attitudinal and behavioural traits of the customers. Oliver (1999) defined attitudinal traits as customers' liking towards the organisation. This liking comes from customers' experiences of satisfaction with a particular product or service. If the customers' experiences regarding satisfaction are positive, it may seem to improve their trust and commitment to the provider (Gustafsson et al., 2005), and they would be more eager to recommend the provider to other customers. Behavioural measures, on the other hand, are related with the use of purchase, repeat purchase and frequency of purchase of the same service (Rundle-Thiele, 2005).

\section{Research hypotheses and conceptual model}

\subsection{Impact of service quality on customer satisfaction}

Service quality helps a service organization gain competitiveness as it is one of the significant factors of satisfying customers (Raza et al., 2020). A number of past researchers have reported the interconnection between service quality and customer satisfaction, indication that greater degree of service quality is more likely to induce greater degree of customer satisfaction (Pooya et al., 2020; Kant and Jaiswal, 2017; Vazifehdoost et al., 2014). The following section presents the development of the hypotheses based on the relationship between the dimensions of service quality and customer satisfaction.

4.1.1 Reliability. Reliability is considered as one of the fundamental factors of service quality that significantly affects customer satisfaction (Zhang et al., 2019). It is essential that the business firms deliver the service accurately in first place. Thus, reliability reflects the capacity to deliver the promised service which is complemented by service accuracy (Ananda and Devesh, 2019). The correctness and perfection of service delivery at first place have been considered as the main feature of a reliable service (Blut, 2016). Customers may not be contended with the service quality in case they perceive the service is not reliable (Hamzah et al., 2017). According to Peng and Moghavvemi (2015), in relation to retaining customers in banking industry, the deciding factors are to process the customer order on time, keep the customers' financial records safe, provide accurate financial information and deliver the guaranteed services. These have been the fundamental attributes of reliability. Pakurár et al. (2019) reported a positive relationship between reliability and banking customers' satisfaction in Jordanian banking context. Based on the above discussion it is proposed that:

H1. Reliability has positive impact on customer satisfaction in the private banking services

4.1.2 Responsiveness. Othman and Owen (2001) stated that responsiveness represents the organizational firm inclination and potentiality to assist customers and to deliver swift customer service. Responsiveness dimension embodies the swiftness of personnel to provide required assistance in a satisfactory and prompt manner (Endara et al., 2019). This dimension is principally related with how service providers react to its customers through their staff. Janahi and Almubarak (2015) opined that skilled frontline employees, proximity of branches and the convenient presence of automated teller machines can be considered as the proper examples of responsiveness in banking industry. Misbach and Hadiwidjojo (2013) suggested that responsiveness has been a critical component which would be essentially taken into consideration by banks with regard to enhancing its customer satisfaction level. Vencataya et al. (2019) validated in their study that responsiveness has been an influential element in predicting customer satisfaction in Mauritius banking sector. Fida et al. (2020) also found a positive relationship between responsiveness and customer satisfaction of Islamic banking services in the Sultanate of Oman. Sardana and Bajpai (2020), in their recent study stated that
Determinants of service quality 
TQM

33,6

responsiveness has been crucial in fulfilling customer expectations (satisfaction) of e-banking service in India. Hence, this study hypothesizes that:

H2. Responsiveness has positive influence on customer satisfaction in the private banking services

4.1.3 Visibility. Visibility relates with appearance of physical components. This dimension usually refers to the practicality or usefulness of any particular good or service (Mersha et al., 2012). According to Othman and Owen (2001), visibility relates with tangible evidence of physical elements, representations, resources, facilities and materials of the service organization. Endara et al. (2019) have opined that service personnel and their uniforms, inside accommodation and service equipment are also part of this dimension. In banking sector, some aspects have been incorporated in visibility dimension which are outlook and cash counters of a bank, privileges of overdraft option, flexible and convenient banking hours and swiftness and accuracy of transaction services, which may have a potential effect on customer satisfaction (Kant and Jaiswal, 2017; Pakurár et al., 2019). Khan et al. (2018) conducted a study on determining customer satisfaction of mobile bank in Bangladesh and found a positive association between service tangibility and customer satisfaction. Therefore, it is hypothesized that:

H3. Visibility has positive influence on customer satisfaction in the private banking services

4.1.4 Employee commitment. Employees are the key in providing quality service to the customers, which actually helps a business firm differentiate from its competitors in the market (Gustaffson, 2009). The service of the frontline personnel is salient in creating and maintaining long lasting relationship and connection with the customers, which ultimately realizes customer satisfaction (Burmann and Konig, 2011). Employee commitment can be conceived as one of the vital contributing components in achieving long-term business growth (Chai et al., 2016). Dhar (2015) contemplates that employee commitment critically contributes to the business firms in attaining competitive advantage towards customer satisfaction. During service interaction, affective commitment for customers is likely to be developed from the employees' perspective that impacts satisfaction level of customers (Bahadur et al., 2018). Hence, this study hypothesizes that:

H4. Employee commitment has positive relationship with customer satisfaction in the private banking services

4.1.5 Access to service. Access indicates how conveniently a service can be accessible and can be reached out swiftly. Access to service means that the service can be smoothly accessible by telecommunication, less waiting time, convenient working hours, and service facility has to be located at a suitable place (Yarimoglu, 2014). Nazeri et al. (2019) noted that convenient accessibility of Internet banking service positively triggers a bank customer's satisfaction. Shayestehfar and Yazdani (2019) have also reported in their comparative study that accessibility has been ranked as the highest indicator of measuring service quality of banking service in the Iranian context. The findings of Khamis and AbRashid (2018) indicate that bank customers are interested and fascinated with those Islamic banks that offer and provide easy and accessible bank services in Tanzania. The study conducted by Kumar et al. (2013) revealed that easy business access hours and convenient branch locations have a strong influence on attracting new customers and retaining existing ones. Based on this, it is hypothesized that:

H5. Access to service has a positive influence on customer satisfaction in the private banking services 


\subsection{Impact of customer satisfaction on customer loyalty}

Research evidence indicated that an interconnected and correlated relationship exist between customer satisfaction and loyalty (Leninkumar, 2017). Usually, satisfied customers avail the same service frequently and speak for the business since satisfied customers tend to be loyal for the business firm as they conceive the service as less unsafe which will lead to make customers more loyal and committed while making the purchase judgement (Teeroovengadum, 2020). Munari et al. (2013) stated that customer satisfaction is the primary foundation to form loyalty. A customer can be regarded as loyal to a service which would significantly reinforce positive customer experience. Moreover, Heskett et al. (2008) argue that retaining highly satisfied customers is the vital driving force of maintaining loyal customers as a part of strategic measure for fostering firm sustainability. Several studies on service industries have documented customer satisfaction as an important variable that garner higher customer loyalty (Slack et al., 2020; Aslam et al., 2019). Past research evidences also point out that customer satisfaction notably mediates the interconnection between service quality and loyalty in banking industry (Fida et al., 2020; Hamzah et al., 2017). Hence, for building a loyal customer base, the fast and foremost important issue for banks is to maintain a sustainable relationship with the customers. Bank service providers may expect that if customers are satisfied with the services provided, then a superior level of customer loyalty can be achieved. Therefore, the research hypothesizes that:

H6. Customer satisfaction has positive relationship with customer loyalty in the private banking services

\subsection{Conceptual model}

Figure 1 represents the conceptual model of the current study which demonstrates the effect of reliability, responsiveness, visibility, employee commitment and access to service on satisfaction of bank customers and the impact of customer satisfaction on loyalty.

\section{Methodology}

In this study, 31 items were used to measure the research variables discussed in the preceding section, and all the items were adapted from the previous studies. The instrument of this research has four sections, namely A, B, C and D. Section A pertains to the respondents' demographic information such as gender, age, education, occupation, type of bank client and experience with the current bank. Section B was developed based on the five dimensions of service quality (i.e. reliability, responsiveness, visibility, employee commitment and access to service) which are adapted from Parasuraman et al. (1988); Choudhury (2014); Kumar et al. (2013); Allen and Grisaffe (2001); Awan (2011). Section C pertains to customer satisfaction (Amin and Isa, 2008). Section D deals with customer loyalty, and corresponding items were adapted from Gustafsson et al. (2005). From Sections B to D, all research variable items were measured using 5-point Likert scale (see summary of survey questionnaire in the Appendix). The present study handled the common method bias by keeping the survey questionnaire short, and all independent and dependent variables are placed in separate sections of the questionnaire according to Podsakoff et al. (2003) and Spector (2006) recommendations. In this study, 320 questionnaires were distributed to the respondents who are the customers of the private banks in Bangladesh. Out of 320 distributed questionnaires, authors received 200 responses that gave a response rate of $62.50 \%$. According to Hair et al. (2010), the sample size for a research similar to the present one should be at least five times the number of items in the questionnaires. Since the present questionnaires had 31 items, therefore, minimum sample size should be 155 . The sample size obtained in the present study fulfilled this minimum requirement. The research data were collected from various places in Bangladesh namely,
Determinants of service quality 
TQM

33,6

1170

Dhaka, Rajshahi, Khulna, Barisal, Chittagong and Comilla. The survey data were analysed based on Pearson correlation analysis, confirmatory factor analysis and structural equation model by using SPSS-22 and AMOS-22 version. In addition to this, analysis of variance and logistic regression methods were applied on customer satisfaction for a number of demographic categorical variables. In addition to the primary method SEM for the present research, the purpose of applying ANOVA and logistic regression is to obtain additional findings that may have some important managerial implications. In order to apply LR, customer satisfaction which was originally a continuous variable has been transformed as a categorical variable. Further details of this test have been provided in the findings section.

\section{Findings}

\subsection{Demographical profile of the respondents}

As mentioned previously, the main objective of this research is to investigate the effect of service quality on customer satisfaction and customer loyalty in the private banking sector of Bangladesh. To pursue this objective, the researchers conducted a survey on a sample of private bank customers of Bangladesh. The respondents' demographic information have been shown in Table 1.

\begin{tabular}{lrr}
\hline Demographic variable & Frequency & Percentage \\
\hline Gender & & \\
Male & 149 & 74.5 \\
Female & 51 & 25.5 \\
Age & & \\
20 years or below & 4 & 2.0 \\
21-30 years & 39 & 19.5 \\
31-40 years & 64 & 32.0 \\
Above 40 years & 93 & 46.5 \\
Educational background & & \\
Bachelor degree & 29 & 14.5 \\
Master's degree & 126 & 63.0 \\
Others & 45 & 22.5 \\
Occupation & & \\
Businessman & 59 & 29.5 \\
Student & 42 & 21.0 \\
Teacher & 26 & 13.0 \\
Doctor & 17 & 8.5 \\
Engineer & 12 & 6.0 \\
Lawyer & 8 & 4.0 \\
Executive & 21 & 10.5 \\
Others & 15 & 7.5 \\
Type of bank client & & \\
Depositor & 129 & 64.5 \\
Borrower & 69 & 34.5 \\
Others & 2 & 1.0 \\
Experience with current bank & & \\
Less than 5 years & 68 & 34.0 \\
5-10 years & 91 & 45.5 \\
11-15 years & 32 & 4.5 \\
Above 15 years & & \\
& & \\
& & \\
& & \\
& & \\
& & \\
& & \\
& &
\end{tabular}

Table 1.

Demographic information on gender, age, educational background and occupation 
According to Table 1, there were more male respondents than their female counterparts. Out of 200 respondents, 149 male respondents represented $74.5 \%$ of the total sample size, whereas 51 were female respondents which represented $25.5 \%$ of the respondents. In this study, different age groups of the respondents participated. The age groups were 20 years or below (2\%), $21-30$ years $(19.5 \%), 31-40$ years $(32 \%)$ and above 40 years $(46.5 \%)$. It was observed that $126(63 \%)$ respondents have master's degree, whereas $29(14.5 \%)$ and $45(22.5 \%)$ respondents had bachelor's degree and other qualifications, respectively. In terms of occupation of the respondents, 59 (29.5\%) were businessman, $42(21 \%)$ were students, 26 $(13 \%)$ were teachers, $21(10.5 \%)$ were executives, $17(8.5 \%)$ were doctors, $12(6 \%)$ were engineers, $8(4 \%)$ were lawyers and $15(7.5 \%)$ had other occupations.

Table 1 also presents that $129(64.5 \%)$ respondents were depositors, whereas 69 (34.5\%) and $2(1 \%)$ respondents were borrowers and others, respectively. In terms of experience with current banking service, $91(45.5 \%)$ respondents have 5-10 years experience with current banking service, whereas $68(34 \%), 32(16 \%)$ and $9(4.5 \%)$ respondents have less than 5 years, 11-15 years and above 15 years experience, respectively.

\subsection{Measurement model}

Prior to applying the structural equation model (SEM), it is required to test the measurement model to observe the appropriateness of the latent variables (Kline, 2011). The confirmatory factor analysis (CFA) indicates the competence of the measurement model with five fit indices, namely chi-square statistic, normed chi-square, comparative fit index (CFI), normed fit index (NFI) and root mean square error of approximation (RMSEA). For the appropriateness of the model fit, normed chi-square value should be less than 5 , NFI and CFI values should be above 0.9 and RMSEA should be less than 0.088 (Hair et al., 2010; Byrne, 2010). Based on the CFA tests, all seven dimensions had adequate model-to-data fit: normed chi square value was 1.420 (below 5.0); NFI and CFI were 0.912 and 0.955 , respectively (above 0.9); and RMSEA value was 0.046 (less than 0.088 ). This study has considered factor loadings and average variance extracted (AVE) to ensure the convergent validity of the constructs.

The measurement model also evaluated the internal consistency and validity of the research variables. The internal consistency of the research variables are measured by the values of Cronbach's alpha and composite reliability (CR), whereas validity is measured by variable item loading and average variance extracted (AVE). According to Hair et al. (2010), above 0.7 of Cronbach's alpha and CR values indicate internal consistency of research variables, whereas above 0.5 of factor loading and AVE value provides strong evidence of convergent validity. Based on the results of measurement model, it was observed that all the seven variables' Cronbach's alpha and CR values were above 0.7 which indicates internal consistency of the research variables (Field, 2009; Hair et al., 2010). The results also indicate that all the variables' AVE values were above 0.5 and all the standardized loadings were above 0.5 which confirm the required convergent validity (see Table 2 ).

\subsection{Structural equation modeling (SEM) and hypotheses testing}

The present study used structural equation modeling (SEM) to test the relationships between independent and dependent variables (Kline, 2011). This study tested a structural model with six hypotheses to estimate the relationships of customer satisfaction with service quality dimensions (i.e., reliability, responsiveness, visibility, employee commitment and access to service) and customer loyalty of private banking service in Bangladesh (see Figure 2). The model had an adequate fit to the data: chi square per degree of freedom $(9.584 / 4)=2.396$, less than $5 ; \mathrm{NFI}=0.989 ; \mathrm{CFI}=0.993$, above $0.9 ; p=0.048$, close to $0.05 ; \mathrm{RMSEA}=0.084$, less than 0.088; and PNFI (Parsimony Normed Fit Index) = 9.16 higher than 0.9 (Hair et al., 2010).
Determinants of service quality 


\section{TQM}

33,6

\begin{tabular}{|c|c|c|c|c|c|}
\hline Variable & Item & $\begin{array}{l}\text { Standard } \\
\text { loadings }\end{array}$ & Cronbach alpha & $\begin{array}{l}\text { Composite reliability } \\
\text { (CR) }\end{array}$ & AVE \\
\hline \multirow[t]{5}{*}{ Reliability } & REL1 & 0.591 & \multirow[t]{5}{*}{0.81} & \multirow[t]{5}{*}{0.84} & \multirow[t]{5}{*}{0.57} \\
\hline & REL2 & 0.505 & & & \\
\hline & REL3 & 0.807 & & & \\
\hline & REL4 & 0.641 & & & \\
\hline & REL5 & 0.721 & & & \\
\hline \multirow[t]{4}{*}{ Responsiveness } & RES1 & 0.656 & \multirow{4}{*}{0.72} & \multirow{4}{*}{0.76} & \multirow{4}{*}{0.52} \\
\hline & RES2 & 0.574 & & & \\
\hline & RES3 & 0.608 & & & \\
\hline & RES4 & 0.554 & & & \\
\hline \multirow[t]{3}{*}{ Visibility } & VISB1 & 0.819 & \multirow[t]{3}{*}{0.76} & \multirow[t]{3}{*}{0.81} & \multirow[t]{3}{*}{0.62} \\
\hline & VISB2 & 0.772 & & & \\
\hline & VISB3 & 0.538 & & & \\
\hline \multirow{4}{*}{$\begin{array}{l}\text { Employee } \\
\text { commitment }\end{array}$} & EMC1 & 0.648 & \multirow[t]{4}{*}{0.72} & \multirow[t]{4}{*}{0.75} & \multirow[t]{4}{*}{0.56} \\
\hline & EMC2 & 0.595 & & & \\
\hline & EMC3 & 0.590 & & & \\
\hline & EMC4 & 0.625 & & & \\
\hline \multirow[t]{3}{*}{ Access to service } & ATS1 & 0.631 & \multirow[t]{3}{*}{0.75} & \multirow[t]{3}{*}{0.79} & \multirow[t]{3}{*}{0.58} \\
\hline & ATS2 & 0.593 & & & \\
\hline & ATS3 & 0.605 & & & \\
\hline \multirow[t]{4}{*}{ Customer satisfaction } & CS1 & 0.511 & \multirow[t]{4}{*}{0.71} & \multirow[t]{4}{*}{0.73} & \multirow[t]{4}{*}{0.55} \\
\hline & CS2 & 0.752 & & & \\
\hline & CS3 & 0.657 & & & \\
\hline & CS4 & 0.546 & & & \\
\hline \multirow{5}{*}{ Customer loyalty } & CL1 & 0.782 & \multirow{5}{*}{0.90} & \multirow{5}{*}{0.94} & \multirow[t]{5}{*}{0.63} \\
\hline & CL2 & 0.836 & & & \\
\hline & CL3 & 0.824 & & & \\
\hline & CL4 & 0.852 & & & \\
\hline & CL5 & 0.672 & & & \\
\hline
\end{tabular}

Table 2.

Construct validity

through confirmatory factory analysis

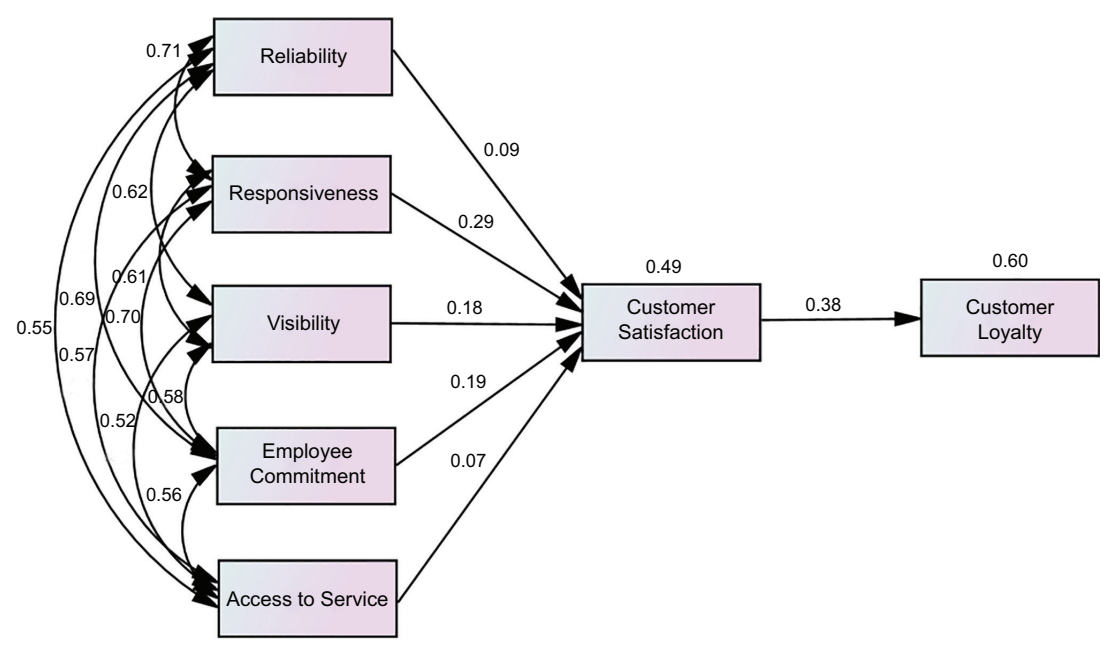

Figure 2.

Structural equation modelling of service quality, customer satisfaction and loyalty in private banking services 
As illustrated in Figure 2, the $R^{2}$ values for the two dependent (endogenous) variables were 0.49 (customer satisfaction) and 0.60 (customer loyalty) which indicated that variations in dependent (endogenous) variables are moderately explained by the independent (exogenous) variables. Based on the SEM analysis, it was observed that the four hypotheses, namely $\mathrm{H} 2, \mathrm{H} 3, \mathrm{H} 4$ and $\mathrm{H} 6$ were supported at $5 \%$ significant level. The findings are also supported by the previous studies of Allen and Grisaffe (2001); Jamal and Naser (2002); Gustafsson et al. (2005); Kumar et al. (2013). However, hypotheses 1 and 5 (H1 and H5) were not supported in the SEM model (see Table 3). The results indicate that reliability does not have significant impact on customer satisfaction in the private banking services of Bangladesh. Some of the previous studies (Kitapci et al., 2013, 2014; Chaniotakis and Lymperopoulos, 2009) also have found that reliability does not have significant influence on customer satisfaction in different contexts. A possible reason for insignificant effect of reliability on customer satisfaction in the present study is that the banking sector might have failed to offer reliable, dependable and trustworthy banking services to the bank clients which might have led them to experience problems with reliability dimension. The research findings also indicate that access to service has insignificant impact on customer satisfaction in the private banking services of Bangladesh. This may be due to poor accessibility of the banking services.

\subsection{Analysis of variance and logistic regression analysis}

Apart from the above SEM analysis, some additional tests such as analysis of variance (ANOVA) and logistic regression (LR) have been performed. Customer satisfaction has been chosen as the dependent variable as this is the prime determinant for gaining customer loyalty and hence a springboard for organisational sustainability. The independent variables considered for ANOVA tests are gender, age, education, occupation, client type and experience. Note that not all the categories of these variables have been considered in the test. The categories where number of respondents is considerably less than the other categories of the same variable are excluded from the analysis. For example, for age, the respondents whose age were 20 years or below are excluded as the number is far lower than the other

\begin{tabular}{|c|c|c|c|}
\hline \multirow[b]{2}{*}{ Types of measure } & \multirow[t]{2}{*}{ el fit summary } & \multirow{2}{*}{$\begin{array}{l}\text { Acceptable } \\
\text { value }\end{array}$} & \multirow{2}{*}{$\begin{array}{l}\text { Observed } \\
\text { value }\end{array}$} \\
\hline & & & \\
\hline Absolute Fit Index - to examine the level of & Normed $\chi^{2}(\mathrm{CMIN} / d f)$ & $\leq 3.0$ & 1.927 \\
\hline effectiveness the model reproduces data & RMSEA & $\leq 0.088$ & 0.084 \\
\hline Incremental Fit Index - model fit to relative & Normed Fit Index (NFI) & $\geq 0.9$ & 0.989 \\
\hline baseline model & $\begin{array}{l}\text { Comparative Fit Index } \\
\text { (CFI) }\end{array}$ & $\geq 0.9$ & 0.993 \\
\hline $\begin{array}{l}\text { Parsimony Fit Index - best model comparing its } \\
\text { fit relative to its complexity }\end{array}$ & $\begin{array}{l}\text { Parsimony Normed Fit } \\
\text { Index (PNFI) }\end{array}$ & $\geq 0.9$ & 0.916 \\
\hline
\end{tabular}

\begin{tabular}{llccc}
\hline & \multicolumn{2}{c}{ Hypothesised path coefficient tests } \\
Relationships & Coefficient $(\beta)$ & C.R. & $p$-value (sig.) \\
\hline H1 & Reliability $\rightarrow$ customer satisfaction & 0.082 & 1.134 & 0.257 \\
H2 & Responsiveness $\rightarrow$ customer satisfaction & 0.272 & 3.478 & 0.001 \\
H3 & Visibility $\rightarrow$ customer satisfaction & 0.187 & 2.604 & 0.009 \\
H4 & Employee commitment $\rightarrow$ customer satisfaction & 0.191 & 2.439 & 0.015 \\
H5 & Access to service $\rightarrow$ customer satisfaction & 0.078 & 1.119 & 0.263 \\
H6 & Customer satisfaction $\rightarrow$ customer loyalty & 0.508 & 6.866 & 0.001
\end{tabular}

Table 3.

Results of structural model fit and hypothesis tests
Determinants of service quality

1173 
TQM

33,6

\section{4}

categories of age. By the same logic, for occupation, the respondents of categories businessman, students and teachers are considered for analysis.

The ANOVA results are shown in Table 4. As it is observed from the significant values, except occupation no other demographic characteristic of the respondents is significant. Therefore, gender, age, education level, client type and experience of the respondents have no effect on their level of satisfaction on bank services. But the type of occupation of the respondents was found to have significant effect on customer satisfaction ( $F$ $(2,123)=12.327, p<0.001)$. Tukey HSD post hoc test reveals that students group $(M=3.265, S D=0.727)$ were significantly less satisfied than businessman group $(M=3.841, S D=0.586, p<0.001)$ and teachers $(M=4.020, S D=0.826, p<0.001)$. Possible reason could be lack of promptness in providing service as students cannot wait long time in the queue for obtaining the necessary service. So, the private banks should be mindful to cater better services to the students group.

Next, a binary logistic regression (LR) analysis was performed considering customer satisfaction as categorical dependent variable. Customer satisfaction was coded as satisfied $(M>3.0)$ and not-satisfied $(M<3.0)$. On the other hand, gender, age, education level, occupation, client type and experience played the role of independent variables. The LR test was run entering all the independent variables at once. The results reveal $-2 L L=58.502$, Nagelkerke $R^{2}=0.446$. The classification results show the hit ratios for not satisfied and satisfied customers and overall as $41.2,94.7$, and $84.8 \%$, respectively. This shows that the logistic regression model is powerful enough to identify the satisfied customers; however, the predicting power of the model for not satisfied customers is rather poor.

Table 5 presents the main results of the LR analysis. The findings confirm the observations made through ANOVA analysis. Only occupation (Wald (2) $=11.897$, $p=0.003$ ) has significant relation with customer satisfaction. The full LR equation is the following:

Logit (customer satisfaction) $=21.214-0.951$ gender (male) -0.139 age $(21-30$ years) +1.027 age (31-40 years) -0.008 education (bachelor's) + 1.826 occupation

\begin{tabular}{lcccc}
\hline Variable & Mean & SD & $F$ & Sig. Value \\
\hline Gender & & & 0.653 & 0.420 \\
Male & 3.686 & 0.723 & & \\
Female & 3.781 & 0.697 & 2.439 & 0.090 \\
Age & & & & \\
21-30 years & 3.589 & 0.597 & & \\
31-40 years & 3.627 & 0.715 & & 0.058 \\
Above 50 years & 3.837 & 0.751 & & \\
Education & & & & \\
Bachelor's & 3.529 & 0.701 & & \\
Master's & 3.810 & 0.704 & & \\
Occupation & & & & \\
Businessman & 3.841 & 0.586 & & \\
Student & 3.265 & 0.727 & & \\
Teacher & 4.020 & 0.826 & & \\
Client type & & & & \\
Depositor & 3.709 & 0.703 & & \\
Borrower & 3.698 & 0.745 & & \\
Experience & & & & \\
Less than 5 years & 3.647 & 0.723 & & \\
5-10 years & 3.750 & 0.731 & & \\
11-15 years & 3.843 & 0.698 & & \\
\end{tabular}

Table 4.

ANOVA results for customer satisfaction as dependent variable (1) 


\begin{tabular}{|c|c|c|c|c|c|c|c|}
\hline Variable & $B$ & S.E. & Wald & $d f$ & Sig & $\operatorname{Exp}(B)$ & Deter \\
\hline Gender (male) & -0.951 & 0.821 & 1.340 & 1 & 0.247 & 0.386 & quality \\
\hline Age & & & 1.625 & 2 & 0.444 & & \\
\hline Age (21-30 years) & -0.139 & 0.882 & 0.025 & $\overline{1}$ & 0.875 & 0.870 & \\
\hline Age (31-40 years) & 1.027 & 0.929 & 1.222 & 1 & 0.269 & 2.792 & \\
\hline Education (Bachelor's) & -0.008 & 0.899 & 0 & 1 & 0.992 & 0.992 & \\
\hline Occupation & & & 11.897 & 2 & 0.003 & & 1175 \\
\hline Occupation (students) & 1.826 & 1.180 & 2.393 & 1 & 0.122 & 6.207 & \\
\hline Occupation (teachers) & -2.082 & 0.883 & 5.557 & 1 & 0.018 & 0.125 & \\
\hline Client type (depositor) & 1.175 & 0.830 & 2.007 & 1 & 0.157 & 3.240 & \\
\hline Experience & & & 2.294 & 2 & 0.318 & & \\
\hline Experience (less than 5 years) & -20.704 & 10630.068 & 0 & 1 & 0.998 & 0 & Binary logistic \\
\hline Experience (5-10 years) & -19.195 & 10630.068 & 0 & 1 & 0.999 & 0 & regression analysis \\
\hline Constant & 21.214 & 10630.068 & 0 & 1 & 0.998 & $1.634 \mathrm{E} 9$ & results \\
\hline
\end{tabular}

(businessman) - 2.082* occupation (students) + 1.175 client type (depositor) - 20.704 experience (less than 5 years) - 19.195 experience (5-10 years).

Note that the exponentiated coefficient for students, which actually represents relative odds for students when compared with teachers, is only 0.125 . This means that students are only 0.125 times more satisfied with respect to teachers, having allowed all other variables in the model. When taken inverse of $\exp (\beta)$, i.e. $-1 / 0.125=8$, it can be concluded that students are eight times more dissatisfied when compared with teachers group.

\section{Discussion}

Based on the research findings it is observed that responsiveness, visibility, employee commitment have significant relationships with customer satisfaction in the private banking sector of Bangladesh. The research findings also indicate that customer satisfaction has positive and significant impact on customer loyalty. However, reliability and access to service have no significant influence on customer satisfaction (see Tables 3 and 6 ). This might be due to the poor quality in bank management system and nonchalant banking service access for the customers. To overcome these problems, banks need to ensure a high level of security in the banking transactions which will increase customers' confidence as well as satisfaction and loyalty (Kumar et al., 2010). Moreover, the banks can open more branches near to customer areas or can introduce other options to access the banking services from anywhere (i.e. online banking facilities) to address the issue of access to service.

\begin{tabular}{|c|c|c|c|}
\hline No & Hypothesized relations & Remark & \\
\hline $\mathrm{H} 1$ & Reliability has positive impact on customer satisfaction in the private banking services & $\begin{array}{l}\text { Not } \\
\text { supported }\end{array}$ & \\
\hline $\mathrm{H} 2$ & $\begin{array}{l}\text { Responsiveness has positive influence on customer satisfaction in the private banking } \\
\text { services }\end{array}$ & Supported & \\
\hline H3 & Visibility has positive influence on customer satisfaction in the private banking services & Supported & \\
\hline $\mathrm{H} 4$ & $\begin{array}{l}\text { Employee commitment has positive relationship with customer satisfaction in the } \\
\text { private banking services }\end{array}$ & Supported & \\
\hline H5 & $\begin{array}{l}\text { Access to service has a positive influence on customer satisfaction in the private } \\
\text { banking services }\end{array}$ & $\begin{array}{l}\text { Not } \\
\text { supported }\end{array}$ & 1 аble \\
\hline $\mathrm{H} 6$ & $\begin{array}{l}\text { Customer satisfaction has positive relationship with customer loyalty in the private } \\
\text { banking services }\end{array}$ & Supported & $\begin{array}{r}\text { Summary results on } \\
\text { hypotheses tests }\end{array}$ \\
\hline
\end{tabular}


TQM

33,6

\section{6}

From the ANOVA and LR analyses, it is concluded that all the demographic characteristics except occupation have no significant impact on customer satisfaction. The results confirm that the student customers are significantly less satisfied compared to other type of customers. Finally, as customers' needs and expectations change over time, the private banks of Bangladesh should dynamically design and progressively deliver better services to satisfy all types of their customers including students.

\section{Managerial implications}

The study has offered some practical implications for the managers of banking organisations. In the study, three variables (responsiveness, visibility and employee commitment) of service quality are reported as significant influencer of customer satisfaction, that would essentially drive customer loyalty; so it is essential for the bank managers to implement the application of these variables to fulfil customer contentment. Since responsiveness is found to be a critical determinant of customer satisfaction, thus bank managers should adopt a comprehensive information/technological infrastructure within the gamut of current banking operations with a view to provide swift and seamless banking service to the customers. Also, bank officials need to be trained sufficiently to provide best possible services. To offer more responsive banking service, bank managers can set up a onestop service centre through which customers' demands and queries can be instantly answered. Bank management needs to focus on increasing the visibility of bank service by adopting newest technology to understand customer needs and serve customers promptly and opening better equipped branches across the country to deliver the financial services and different customized products to the customers, which would eventually fulfil customer needs and create more loyal customers. Furthermore, bank managers have to provide necessary training sessions and financial and non-financial rewards to their staff so that bank staff will remain committed, motivated, connected, empathetic to customers and deliver the fast track, suitable and reliable services towards the customers and create greater level of customer fulfilment and satisfaction.

\section{Conclusions}

Numerous research studies have found strongly positive relationship between service quality and customer satisfaction and then between customer satisfaction and customer loyalty. The present study has established, once again, the above relationships in the context of private banking sector of Bangladesh. In particular, from among the five dimensions of service quality, namely responsiveness, visibility and employee commitment are found to have significant positive relationships with customer satisfaction. Notably, all these dimensions are related with employees working in the banking sector. Hence private banking sector of Bangladesh should pay sufficient attention to provide training on continuous basis to their employees. In this way, the banking sector can increase their customers' satisfaction level and hence their revenue. In addition to this, it is also concluded that the bank managers should pay special attention to fulfil the expectations of their customers who are students of various colleges or universities.

The major limitation of this research has been linked with the geographical area of data collection. Although the study has collected data from the major cities in Bangladesh, still the generalizability of the research findings may not be applicable to other countries. Thus, cross country sampling and longitudinal research technique can be adopted in future studies for the purpose of evaluation of the customers' perception towards banking service quality for more comprehensive and robust results. Another limitation of the study is the consideration of measuring service quality of general banking services. Hence, future studies might be 
interested into measuring the service quality of automated teller machine (ATM) or Internet banking service of different financial organizations in cross country context.

\section{References}

Ahrholdt, D.C., Gudergan, S.P. and Ringle, C.M. (2017), "Enhancing service loyalty: the roles of delight, satisfaction, and service quality", Journal of Travel Research, Vol. 56 No. 4, pp. 436-450.

Al-jazzazi, A. and Sultan, P. (2017), "Demographic differences in Jordanian bank service quality perceptions", International Journal of Bank Marketing, Vol. 35 No. 2, pp. 275-297.

Allen, N.J. and Grisaffe, D.B. (2001), "Employee commitment to the organisation and customer reactions: mapping the linkages", Human Resource Management Review, Vol. 11 No. 3, pp. 209-236.

Amin, M. and Isa, Z. (2008), "An examination of the relationship between service quality perception and customer satisfaction: a SEM approach towards Malaysian Islamic banking", International Journal of Islamic and Middle Eastern Finance and Management, Vol. 1 No. 3, pp. 191-209.

Ananda, S. and Devesh, S. (2019), "Service quality dimensions and customer satisfaction: empirical evidence from retail banking sector in Oman", Total Quality Management and Business Excellence, Vol. 30 Nos 15-16, pp. 1616-1629.

Anouze, A.L.M. and Alamro, A.S. (2019), "Factors affecting intention to use e-banking in Jordan", International Journal of Bank Marketing, Vol. 38 No. 1, pp. 86-112.

Aslam, W., Tariq, A. and Arif, I. (2019), "The effect of ATM service quality on customer satisfaction and customer loyalty: an empirical analysis", Global Business Review, Vol. 20 No. 5, pp. 1155-1178.

Asnawi, N., Sukoco, B.M. and Fanani, M.A. (2019), "The role of service quality within Indonesian customers satisfaction and loyalty and its impact on Islamic banks", Journal of Islamic Marketing, Vol. 11 No. 1, pp. 192-212.

Awan, M.H., Bukhari, S.K. and Iqbal, A. (2011), "Service quality and customer satisfaction in the banking sector: a comparative study of conventional and Islamic banks in Pakistan", Journal of Islamic Marketing, Vol. 2 No. 3, pp. 203-224.

Ayadi, R., Arbak, E., Naceur, S.B. and De Groen, W.P. (2015), "Financial development, bank efficiency and economic growth across the mediterranean", Economic and Social Development of the Southern and Eastern Mediterranean Countries, Springer International Publishing, pp. 219-233.

Bahadur, W., Aziz, S. and Zulfiqar, S. (2018), "Effect of employee empathy on customer satisfaction and loyalty during employee-customer interactions: the mediating role of customer affective commitment and perceived service quality", Cogent Business and Management, Vol. 5 No. 1, pp. 1-21.

Berry, L.L., Bennet, D.R. and Brown, C.W. (1989), Service Quality: A Profit Strategy for Financial Institutions, Dow-Jones-Irwin, Homewood, IL.

Bhat, S.A., Darzi, M.A. and Parrey, S.H. (2018), "Antecedents of customer loyalty in banking sector: a mediational study”, Vikalpa, Vol. 43 No. 2, pp. 92-105.

Blut, M. (2016), "E-service quality: development of a hierarchical model”, Journal of Retailing, Vol. 92 No. 4, pp. 500-517.

Boonlertvanich, K. (2019), "Service quality, satisfaction, trust, and loyalty: the moderating role of mainbank and wealth status”, International Journal of Bank Marketing, Vol. 37 No. 1, pp. 278-302.

Burmann, C. and Konig, V. (2011), "Does internal brand management really drive brand commitment in shared-service call centers?", Journal of Brand Management, Vol. 18 No. 6, pp. 374-393.

Byrne, B.M. (2010), Structural Equation Modelling with AMOS: Basic Concepts, Application, and Programming, 2nd ed., Routledge, New York.

Cadotte, E.R., Woodruff, R.B. and Jenkins, R.L. (1987), "Expectations and norms in models of consumer satisfaction”, Journal of Marketing Research, Vol. 24 No. 3, pp. 305-314.

Caruana, A. (2002), "Service loyalty: the effects of service quality and the mediating role of customer satisfaction”, European Journal of Marketing, Vol. 36 Nos 7/8, pp. 811-828.
Determinants of service quality 
TQM

33,6

Chai, B.B.H., Tan, P.S. and Goh, T.S. (2016), "Banking services that influence the bank performance", Procedia-Social and Behavioral Sciences, Vol. 224, pp. 401-407.

Chaniotakis, I.E. and Lymperopoulos, C. (2009), "Service quality effect on satisfaction and word of mouth in the health care industry", Managing Service Quality: International Journal, Vol. 19 No. 2, pp. 229-242.

Cheshin, A., Amit, A. and van Kleef, G.A. (2018), "The interpersonal effects of emotion intensity in customer service: perceived appropriateness and authenticity of attendants' emotional displays shape customer trust and satisfaction”, Organizational Behavior and Human Decision Processes, Vol. 144, pp. 97-111.

Choudhury, K. (2014), "Service Quality and word of mouth: a study of the banking sector", International Journal of Bank Marketing, Vol. 32 No. 7, pp. 612-627.

Dhar, R.L. (2015), "Service quality and the training of employees: the mediating role of organizational commitment”, Tourism Management, Vol. 46, pp. 419-430.

Endara, Y.M., Ali, A.B. and Yajid, M.S.A. (2019), "The influence of culture on service quality leading to customer satisfaction and moderation role of type of bank", Journal of Islamic Accounting and Business Research, Vol. 10 No. 1, pp. 134-154.

Fida, B.A., Ahmed, U., Al-Balushi, Y. and Singh, D. (2020), "Impact of service quality on customer loyalty and customer satisfaction in Islamic banks in the sultanate of Oman", Sage Open, Vol. 10 No. 2, pp. 1-10.

Field, A. (2009), Discovering Statistics Using SPSS, 3rd ed., Sage Publications, London.

Gounaris, S., Stathakopoulos, V. and Athanassopoulos, A. (2003), "Antecedents to perceived service quality: an exploratory study in the banking industry", International Journal of Bank Marketing, Vol. 21 No. 4, pp. 168-190.

Grönroos, C. (1984), “A service quality model and its marketing implication”, European Journal of Marketing, Vol. 18 No. 4, pp. 38-44.

Gustaffson, A. (2009), "Customer satisfaction with service recovery", Journal of Business Research, Vol. 62 No. 8, pp. 1220-1222.

Gustafsson, A., Johnson, M.D. and Roos, I. (2005), "The effects of customer satisfaction, relationship commitment dimensions, and triggers on customer retention", Journal of Marketing, Vol. 69 No. 4, pp. 210-218.

Hair, J.F., Black, W.C., Babin, B.J. and Anderson, R.E. (2010), Multivariate Data Analysis: A Global Perspective, 7th ed., Pearson Prentice Hall, New Jersey.

Hamzah, Z.L., Lee, S.P. and Moghavvemi, S. (2017), "Elucidating perceived overall service quality in retail banking", International Journal of Bank Marketing, Vol. 35 No. 5, pp. 781-804.

Heskett, J.L., Sasser, W.E. and Schlesinger, L.A. (1997), The Service Profit Chain: How Leading Companies Link Profit and Growth to Loyalty, Satisfaction and Value, Free Press, New York.

Heskett, J.L., Jones, T.O., Loveman, G.W., Sasser, W.E. Jr and Schlesinger, L.A. (2008), "Putting the service-profit chain to work", Harvard Business Review, Vol. 86, pp. 118-129.

Hossain, M.A. and Dwivedi, Y.K. (2015), "Determining the consequents of bank's service quality with mediating and moderating effects: an empirical study", Total Quality Management and Business Excellence, Vol. 26 Nos 5/6, pp. 661-674.

Hossain, M.A., Dwivedi, Y.K. and Naseem, S. (2015), "Developing and validating a hierarchical model of service quality of retail banks", Total Quality Management and Business Excellence, Vol. 26 Nos 5/6, pp. 534-549.

Jamal, A. and Naser, K. (2002), "Customer satisfaction and retail banking: an assessment of some of the key antecedents of customer satisfaction in retail banking", International Journal of Bank Marketing, Vol. 20 No. 4, pp. 146-160.

Janahi, M.A. and Almubarak, M. (2015), "The impact of customer service quality on customer satisfaction in Islamic banking”, Journal of Islamic Marketing, Vol. 8 No. 4, pp. 595-604. 
Kant, R. and Jaiswal, D. (2017), "The impact of perceived service quality dimensions on customer satisfaction: an empirical study on public sector banks in India”, International Journal of Bank Marketing, Vol. 35 No. 3, pp. 411-430.

Kashif, M., Shukran, S.S.W., Rehman, M.A. and Sarifuddin, S. (2015), "Customer satisfaction and loyalty in Malaysian Islamic banks: a PAKSERV investigation", International Journal of Bank Marketing, Vol. 33 No. 1, pp. 23-40.

Kaur, H. and Soch, H. (2018), "Satisfaction, trust and loyalty: investigating the mediating effects of commitment, switching costs and corporate image", Journal of Asia Business Studies, Vol. 12 No. 4, pp. 361-380.

Khamis, F.M. and AbRashid, R. (2018), "Service quality and customer's satisfaction in Tanzania's Islamic banks: a case study at People's Bank of Zanzibar (PBZ)", Journal of Islamic Marketing, Vol. 9 No. 4, pp. 884-900.

Khan, A.G., Lima, R.P. and Mahmud, M.S. (2018), "Understanding the service quality and customer satisfaction of mobile banking in Bangladesh: using a structural equation model", Global Business Review, Vol. 5, pp. 1-16.

Kitapci, O., Taylan Dortyol, I., Yaman, Z. and Gulmez, M. (2013), "The paths from service quality dimensions to customer loyalty: an application on supermarket customers", Management Research Review, Vol. 36 No. 3, pp. 239-255.

Kitapci, O., Akdogan, C. and Dortyol, İ.T. (2014), "The impact of service quality dimensions on patient satisfaction, repurchase intentions and word-of-mouth communication in the public healthcare industry", Procedia-Social and Behavioral Sciences, Vol. 148, pp. 161-169.

Kline, R.B. (2011), Principles and Practice of Structural Equation Modelling, 3rd ed., Guilford Press, New York.

Kotler, P. and Keller, K.L. (2013), Marketing Management, 14th ed., Pearson Education, Upper Saddle River, New Jersey.

Kumar, M., Tat Kee, F. and Charles, V. (2010), "Comparative evaluation of critical factors in delivering service quality of banks", International Journal of Quality and Reliability Management, Vol. 27 No. 3, pp. 351-377.

Kumar, A., Road, M.L. and Dash, M.K. (2013), "Constructing a measurement in service quality for Indian banks: structual equation modelling approach", Journal of Internet Banking and Commerce, Vol. 18 No. 1, pp. 1-13.

Leninkumar, V. (2017), "The relationship between customer satisfaction and customer trust on loyalty”, International Journal of Academic Research in Business and Social Sciences, Vol. 7, pp. $450-464$.

Levy, S. and Hino, H. (2016), "Emotional brand attachment: a factor in customer-bank relationships", International Journal of Bank Marketing, Vol. 34 No. 2, pp. 136-150.

Mainardes, E.W., Rosa, C.A.D.M. and Nossa, S.N. (2020), "Omnichannel strategy and customer loyalty in banking", International Journal of Bank Marketing, Vol. 38 No. 4, pp. 799-822.

Makanyeza, C. and Chikazhe, L. (2017), "Mediators of the relationship between service quality and customer loyalty: evidence from the banking sector in Zimbabwe", International Journal of Bank Marketing, Vol. 35 No. 3, pp. 540-556.

Mersha, T., Sriram, V., Yeshanew, H. and Gebre, Y. (2012), "Perceived service quality in Ethiopian retail banks", Thunderbird International Business Review, Vol. 54 No. 4, pp. 551-565.

Mihelis, G., Grigoroudis, E., Siskos, Y., Politis, Y. and Malandrakis, Y. (2001), "Customer satisfaction measurement in the private bank sector", European Journal of Operational Research, Vol. 130 No. 2, pp. 347-360.

Misbach, I. and Hadiwidjojo, D. (2013), "Islamic bank service quality and trust: study on islamic bank in makassar Indonesia", International Journal of Business and Management, Vol. 8 No. 5, pp. 48-61.

Munari, L., Ielasi, F. and Bajetta, L. (2013), "Customer satisfaction management in Italian banks", Qualitative Research in Financial Markets, Vol. 5 No. 2, pp. 139-160. 
TQM

33,6

Nambiar, B.K., Ramanathan, H.N., Rana, S. and Prashar, S. (2018), "Perceived service quality and customer satisfaction: a missing link in Indian banking sector", Vision, Vol. 23 No. 1, pp. 44-55.

Narteh, B. (2018), "Service quality and customer satisfaction in Ghanaian retail banks: the moderating role of price", International Journal of Bank Marketing, Vol. 36 No. 1, pp. 68-88.

Nazeri, A., Soofifard, R., Ebrahimi, M. and Babayof, L. (2019), "The effect of the internet banking service quality on customer satisfaction (case study: refah bank in Tehran)", International Journal of Services and Operations Management, Vol. 34 No. 1, pp. 65-80.

Oh, H. and Kim, K. (2017), "Customer satisfaction, service quality, and customer value: years 20002015", International Journal of Contemporary Hospitality Management, Vol. 29 No. 1, pp. 2-29.

Oliver, R.L. (1999), "Whence consumer loyalty?", The Journal of Marketing, Vol. 63, pp. 33-44, (special issue).

Ong, K.S., Nguyen, B. and Syed Alwi, S.F. (2017), "Consumer-based virtual brand personality (CBVBP), customer satisfaction and brand loyalty in the online banking industry", International Journal of Bank Marketing, Vol. 35 No. 3, pp. 370-390.

Othman, A. and Owen, L. (2001), "Adopting and measuring customer service quality (SQ) in Islamic banks: a case study in Kuwait finance house", International Journal of Islamic Financial Services, Vol. 3 No. 1, pp. 1-26.

Özkan, P., Süer, S., Keser, İ.K. and Kocakoç, İ.D. (2019), "The effect of service quality and customer satisfaction on customer loyalty: the mediation of perceived value of services, corporate image, and corporate reputation", International Journal of Bank Marketing, Vol. 38 No. 2, pp. 384-405.

Pakurár, M., Haddad, H., Nagy, J., Popp, J. and Oláh, J. (2019), “The service quality dimensions that affect customer satisfaction in the Jordanian banking sector", Sustainability, Vol. 11 No. 4, pp. 1-24.

Palmer, A. (2001), Principles of Service Marketing, McGraw-Hill, New York.

Parasuraman, A., Zeithaml, V.A. and Berry, L.L. (1988), "SERVQUAL: a multi-item scale for measuring consumer perceptions of service quality", Journal of Retailing, Vol. 64 No. 1, pp. 12-40.

Peng, L.S. and Moghavvemi, S. (2015), "The dimension of service quality and its impact on customer satisfaction, trust, and loyalty: a case of Malaysian banks", Asian Journal of Business and Accounting, Vol. 8 No. 2, pp. 91-122.

Podsakoff, P.M., MacKenzie, S.B., Lee, J.Y. and Podsakoff, N.P. (2003), "Common method biases in behavioral research: a critical review of the literature and recommended remedies", Journal of Applied Psychology, Vol. 88 No. 5, pp. 879-903.

Pooya, A., Abed Khorasani, M. and Gholamian Ghouzhdi, S. (2020), "Investigating the effect of perceived quality of self-service banking on customer satisfaction", International Journal of Islamic and Middle Eastern Finance and Management, Vol. 13 No. 2, pp. 263-280.

Raza, S.A., Umer, A., Qureshi, M.A. and Dahri, A.S. (2020), "Internet banking service quality, ecustomer satisfaction and loyalty: the modified e-SERVQUAL model", The TQM Journal, Vol. 32 No. 6, pp. 1443-1466, doi: 10.1108/TQM-02-2020-0019.

Rundle-Thiele, S. (2005), "Exploring loyal qualities: assessing survey-based loyalty measures”, Journal of Services Marketing, Vol. 19 No. 7, pp. 492-500.

Saleh, M.A., Quazi, A., Keating, B. and Gaur, S. (2017), "Quality and image of banking services: a comparative study of conventional and Islamic banks", International Journal of Bank Marketing, Vol. 35 No. 6, pp. 878-902.

Sardana, S. and Bajpai, V.N. (2020), "E-banking service quality and customer satisfaction: an exploratory study on India”, International Journal of Services and Operations Management, Vol. 35 No. 2, pp. 223-247.

Shayestehfar, R. and Yazdani, B. (2019), "Bank service quality: a comparison of service quality between BSI branches in Isfahan and Dubai”, The TQM Journal, Vol. 31 No. 1, pp. 28-51.

Silvestri, C., Aquilani, B. and Ruggieri, A. (2017), "Service quality and customer satisfaction in thermal tourism”, The TQM Journal, Vol. 29 No. 1, pp. 55-81. 
Singla, V. (2012), "Role of service quality and customer satisfaction in predicting customer loyalty", Journal for Global Business Advancement, Vol. 5 No. 3, pp. 248-259.

Slack, N., Singh, G. and Sharma, S. (2020), "The effect of supermarket service quality dimensions and customer satisfaction on customer loyalty and disloyalty dimensions", International Journal of Quality and Service Sciences, ahead-of-print No. ahead-of-print, doi: 10.1108/IJQSS-10-2019-0114.

Spector, P.E. (2006), "Method variance in organisational research truth or urban legend?", Organisational Research Methods, Vol. 9 No. 2, pp. 221-232.

Spreng, R.A. and MacKoy, R.D. (1996), "An empirical examination of a model of perceived service quality and satisfaction", Journal of Retailing, Vol. 72 No. 2, pp. 201-214.

Teeroovengadum, V. (2020), "Service quality dimensions as predictors of customer satisfaction and loyalty in the banking industry: moderating effects of gender", European Business Review, ahead-of-print, No. ahead-of-print, doi: 10.1108/EBR-10-2019-0270.

Vazifehdoost, H., Akbarpour, Z., Hamdi, K. and Mohammadzadeh Rostami, J. (2014), "The examination of the relationship between customer satisfaction of service quality in Iranian private banking industry (analysis based on integrated SERVQUAL model)", Journal of Marketing Management, Vol. 9 No. 25, pp. 1-24.

Vencataya, L., Pudaruth, S., Juwaheer, R.T., Dirpal, G. and Sumodhee, N.M.Z. (2019), “Assessing the impact of service quality dimensions on customer satisfaction in commercial banks of Mauritius", Studies in Business and Economics, Vol. 14 No. 1, pp. 259-270.

Wang, Y., Lo, H. and Hui, Y.V. (2003), "The antecedents of service quality and product quality and their influences on bank reputation: evidence from the banking industry in China”, Managing Service Quality, Vol. 13 No. 1, pp. 72-83.

Yalley, A.A. and Agyapong, G.K. (2017), "Measuring service quality in Ghana: a crossvergence cultural perspective", Journal of Financial Services Marketing, Vol. 22 No. 2, pp. 43-53.

Yarimoglu, E.K. (2014), “A review on dimensions of service quality models”, Journal of Marketing Management, Vol. 2 No. 2, pp. 79-93.

Yilmaz, V., Ari, E. and Gürbüz, H. (2018), "Investigating the relationship between service quality dimensions, customer satisfaction and loyalty in Turkish banking sector: an application of structural equation model”, International Journal of Bank Marketing, Vol. 36 No. 3, pp. 423-440.

Zeithaml, V.A., Parasuraman, A. and Berry, L.L. (1990), Delivering Quality Service: Balancing Customer Perceptions and Expectations, The Free Press, New York. NY.

Zeithaml, V.A., Berry, L.L. and Parasuraman, A. (1996), "The behavioural consequences of service quality", The Journal of Marketing, pp. 31-46.

Zhang, C., Liu, Y., Lu, W. and Xiao, G. (2019), "Evaluating passenger satisfaction index based on PLSSEM model: evidence from Chinese public transport service", Transportation Research Part A: Policy and Practice, Vol. 120, pp. 149-164.

Zhou, L. (2004), "A dimension-specific analysis of performance-only measurement of service quality and satisfaction in China's retail banking", The Journal of Services Marketing, Vol. 18 No. 7, pp. 534-546.

\section{Further reading}

Ramdhani, M.A., Ramdhani, A. and Kurniati, D.M. (2011), "The Influence of service quality toward customer satisfaction of Islamic sharia bank", Australian Journal of Basic and Applied Sciences, Vol. 5 No. 9, pp. 1099-1104.
Determinants of service quality 
TQM 33,6

Appendix

Summary of survey questionnaire

Code Items Sources

Reliability

REL1 When the bank promised to do something by a certain time, it Parasuraman et al. (1988) does so

REL2 Bank shows a sincere interest to solve my problem

REL3 Bank inform me exactly when services will be performed

REL4 Bank provide services at the time it promised to do so

REL5 Bank employees give me prompt service

Responsiveness

RES1 Bank employees are never be too busy to respond my request Parasuraman et al. (1988),

RES2 Bank employees understand my specific needs Choudhury (2014)

RES3 Bank has the employees who give me individual attention

RES4 Bank has the clients' best interest at heart

Visibility

VISB1 Bank has up-to-date equipment

VISB2 Physical facilities of the bank are visually appealing

VISB3 Bank employees are well dressed and neat in appearance

Employee Commitment

EMC1 Bank employees are consistently polite with customers

EMC2 Bank employees are professional to provide services

EMC3 Bank employees show their interest to help the customers

EMC4 Feel confident to deal with bank because of employee commitment in banking service

Access to Service

ATS1 Easily can depend on the banking service

ATS2 Location of the bank branch is convenient

ATS3 Operating hour of the bank is convenient

Kumar et al. (2013)

Customer Satisfaction

CS1 Satisfied with banking services

CS2 Satisfied with banking operations

CS3 Satisfied with the total system provided by the bank

CS4 Satisfied with the bank as it is originated in Bangladesh

Customer Loyalty

CL1 Recommend to the relatives and friends to use my bank

CL2 I will continue to use this banking service in the future

CL3 My bank is more interesting than others

CL4 Feel delighted for choosing the service of the bank

CL5 Feel positive image when hear the name of my bank

Allen and Grisaffe (2001)

Awan (2011)

Amin and Isa (2008)

Gustafsson et al. (2005)

Corresponding author

Rafikul Islam can be contacted at: rislam@iium.edu.my

For instructions on how to order reprints of this article, please visit our website:

www.emeraldgrouppublishing.com/licensing/reprints.htm

Or contact us for further details: permissions@emeraldinsight.com 